\title{
Effect of pH on the Removal of Chromium (Cr) (VI) by Sugar Cane Bagasse
}

\author{
Nasim Ahmed Khan, Syed Iqbal Ali and Sohail Ayub
}

Department of Civil Engineering, AMU. Aligarh University Polytechnic. AMU. Aligarh, India.

\author{
تألثير درجة الحموضةف إزالة الكرو (VI) بلستخدلم بقلس من قصب السكر
}

\section{غسيم أحمدخل سسيد فبل علي وسهل أليوب}

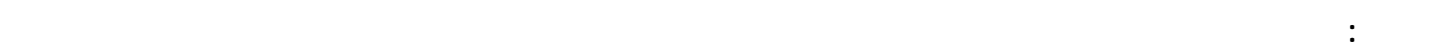

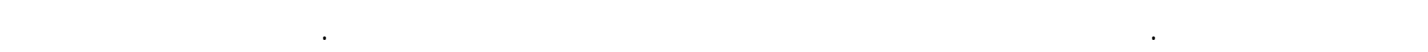

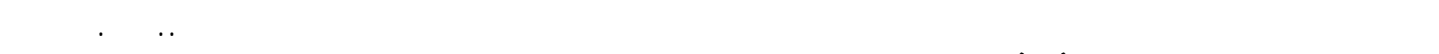

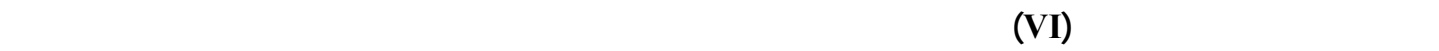

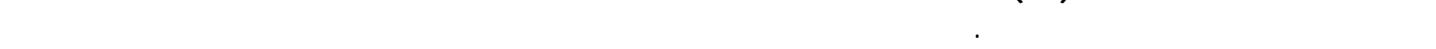

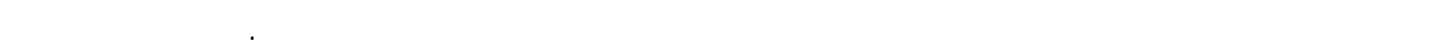

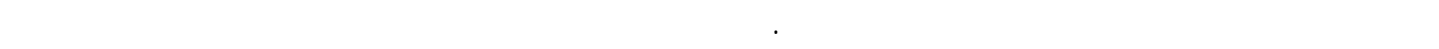

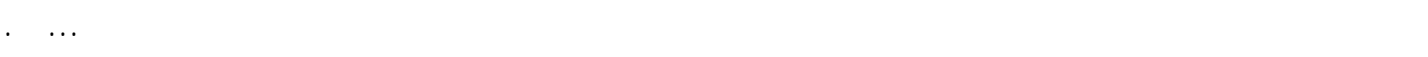

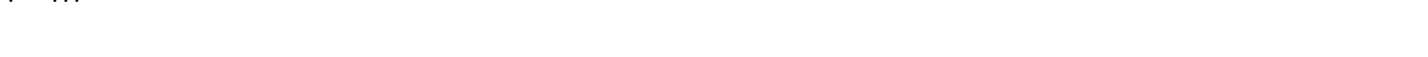

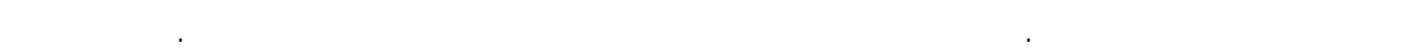

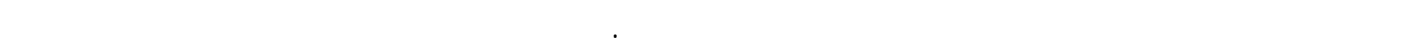
لاستخدلم بقلسسكر القصب لإزالة معنن الكروم (VI) من المحاليل المائية.

ABSTRACT: The industrial estates in India are dominated by small and medium scale industries, which are posing a serious threat to the environment by virtue of discharging effluents of a polluting nature. The problems become severe due to the presence of heavy metals in the effluents. Chromium is widely used in a number of industries such as electroplating, metal finishing, cooling towers, dyes, paints, anodising and leather tanning industries. The toxicity of chromium (VI) is well known and is considered a hazard to the health of humans and animals. The presence of chromium (VI) in aquatic environments at high concentrations is also lethal to marine species. The treatment of chromium bearing effluents have been reported through several methods, such as chemical reduction, precipitation, ion exchange, electrochemical reduction, evaporation, reverse osmosis and adsorption. However among these, adsorption is found to be highly effective, inexpensive and an easy method to operate. India is an agricultural country and generates a considerable amount of agricultural wastes such as sugar cane bagassess, coconut jute, nut shell, rice straw, rice husk, waste tea leaves, ground nut husk, crop wastes, peanut hulls and fertilizer wastes. Successful studies on these materials could be beneficial to developing countries and could be easily applied as adsorbents for the removal of chromium from wastewater. Most of the previous work highlights the use of commercial activated carbon but these adsorbents are relatively expensive and less feasible to be used in developing countries. Keeping these in view batch experiments have been designed to study the feasibility of sugar cane bagasse to remove chromium (VI) from the aqueous solutions. While evaluationg the impact of various parameters, such as adsorbent does, contact time, initial concentration and $\mathrm{pH}$ on chromium removal efficiency, the results indicate a prominent effect of $\mathrm{pH}$ on the chromium reduction by the adsorbent used in the present study.

KEYWORDS: Adsorption, Toxicity, Sugarcane, Bagasse and Chromium.

\section{Introduction}

Most of the wastewater in industrial estates contains trace quantities of many heavy metals such as nickel, manganese, lead, chromium, cadmium, zinc, copper, iron and mercury. Some of 
these metals are essential to the growth of biological life and absence of sufficient quantities of them could limit their growth (Metacalf and Eddy et al, 1994). Larger concentrations, however, could cause adverse effects on humans, animals and plants. The rapid industrialization has resulted in accelerating the flux of heavy metals into surfacial environment. Pollution, due to these heavy metals, has been a major source of concern to scientists and environmental engineers. The presence of any of the above mentioned heavy metals in excessive quantity will interfere with many usages of water because of their toxicity. Therefore, it is desirable to measure and control the concentrations of these substances. Several mishaps related to heavy metal concentrations in the aquatic environment have increased the awareness about heavy metal toxicity. Among these, Minamata tragedy in Japan (1953-60) due to metallic mercury escaping from the laboratories and industries, mainly from chlorine manufacturing. It was acquired by aquatic life and passed along through natural food chains to humans, largely by fish. Another disease "Itai-Itai" that occurred among the farmers who drank water-containing cadmium supplied from the Jentsu River in Japan (Benefield ; Jadleins and Weand et al, 1982).

Chromium (VI) causes many adverse effects on humans, aquatic life and soil. Some of the effects are summarized as follows; Humans: Nausea, vomiting (Kerishnamurthy and Vishwanathan), epiesgestric pain, severe diarrhoea, haemorrhage, dermatitis by skin contact, nasal mucous membrane, ulcer (Satyanarayan et al, 1995), lung cancer and tissue necrosis. Aquatic life: reduction in fish production at high concentrations, chromium accumulates in fish tissues and reaches to consumers. Gold fish and trout are killed at a concentration of $180 \mathrm{mg} / \mathrm{l}$. Land: Soil fertility is reduced if chromium-bearing effluents are discharged on land (Sohail, 1997).

Table 1: Comparative study of different adsorbents (Siddiqui, Z. M. and Paroor, S. 1994).

\begin{tabular}{|l|c|c|c|c|c|}
\hline \multicolumn{1}{|c|}{ Adsorbent } & $\begin{array}{c}\text { Initial } \\
\text { conc.Cr } \\
\text { (VI) mg/l }\end{array}$ & $\begin{array}{c}\text { Equilibrium } \\
\text { time(hr) }\end{array}$ & $\begin{array}{c}\text { Dose } \\
(\mathbf{g} / \mathbf{1 0 0} \mathbf{m l})\end{array}$ & $\mathbf{p H}$ & Cr (VI) removal \% \\
\hline Activated GHC [8] & 10 & 3 & 0.24 & 2 & 80 \\
\hline Activated charcoal [2] & 100 & - & 5 & - & 100 \\
\hline Calcinate coke [5] & 5 & - & - & 2 & 100 \\
\hline Bagasse ash [10] & 10 & 3 & 6 & 2 & 53.2 \\
\hline Activated bagasse carbon [10] & 10 & 1.5 & 1.0 & $0.85-2$ & 99.97 \\
\hline Raw bagasse [10] & 10 & 1.5 & 1.0 & 1.0 & 93.5 \\
\hline Activated coconut jute [10] & 10 & 1.5 & 1.0 & $1.4-2$ & 99.7 \\
\hline Waste tea leaves carbon [7] & - & - & 1.2 & 2 & 100 \\
\hline $\begin{array}{l}\text { Activated charcoal, Flyash \& } \\
\text { rice husk [11] }\end{array}$ & - & $7,-, 0.5$ & - & $0-2$ & $50,-, 100$ \\
\hline Carbon slurry [12] & - & 1.0 & 0.8 & 2.5 & 91.50 \\
\hline Rice straw [3] & 10 & 24 & 1.0 & $1-3$ & 100 \\
\hline Activated charcoal [6] & 10 & - & 0.5 & 3 & Max at pH 3 \\
\hline Peat [9] & 100 & 24 & $0.4-4$ & $>2$ & 50 \\
\hline Fe(III) hydroxide [1] & 50.8 & - & 0.30 & $4-6$ & 99 \\
\hline Lignite [13] & 3000 & 24 & 0.4 & 2 & 73.33 \\
\hline Activated carbon [4] & 5.0 & 2 & 0.2 & 2.5 & 100 \\
\hline
\end{tabular}

\section{Adsorption of Heavy Metals on Agricultural Wastes}

The treatment of chromium bearing effluents has been reported through several methods, such as, chemical reduction and precipitation, ion exchange, electrochemical reduction, evaporation and reverse osmosis. Most of these methods need high capital costs and recurring expenses such as chemicals. Less attention has been paid towards the treatment of effluent containing chromium by means of the adsorption technique using agricultural wastes. (Sohail et al, 1998). Potential Agricultural waste adsorbents are activated ground nut husk carbon (Periasamy, 1991), calcinate coke (Satyanarayan, 1995), bagasse ash, activated coconut jute, waste tea leaves carbon, activated 
charcoal, fly ash and rice husk, and rice straw (Deo, 1992). The comparative studies of different adsorbents are shown in Table 1 (Lal, 1992; Huang, 1975; Sharma, 1993; Shrichand, 1994).

\section{Materials and Methods}

The wastewater to be used in the investigation was prepared by dissolving a known amount of potassium dichromate in a known volume of distilled water in order to have waste of uniform characteristics and to avoid the interference with other elements. To evaluate the potential of bagasse to remove hexavalent chromium, batch experiments were carried out. Wastewater containing known concentrations of $\mathrm{Cr}$ (VI) were prepared from the stock solution and taken separately in glass stoppered conical flasks. Then known quantities of the adsorbent were added to the wastewater. The system was equilibrated by shaking the contents of the flask at room temperature so that adequate contact time between adsorbent and the metal ion was maintained. The suspension was filtered through Whatman No.1 filter paper and the filtrate was analyzed to evaluate the concentration of $\mathrm{Cr}$ (VI) metal in the treated wastewater. All the analyses were performed according to Standard Methods (Standard Methods, 1989). Metal analysis was carried out by using Atomic Absorption Spectrometry (model: GBC- 902).

\section{Results and Discussion}

While evaluating the effect of adsorbent dose, contact time and $\mathrm{pH}$ on chromium removal, the initial concentration of $\mathrm{Cr}$ (VI) was kept as $50 \mathrm{mg} / \mathrm{l}$ because in chrome plating wastes, chromium concentrations vary from 3-30 mg/1 [ISI 7453-1977].

\section{Effects of Contact Time at Different Adsorbent Doses on Cr (VI) Removal}

The response of contact time on the removal of $\mathrm{Cr}$ (VI) is presented in Figure1. The observations reveal that the percentage of removal of $\mathrm{Cr}$ (VI) increases with an increase in contact

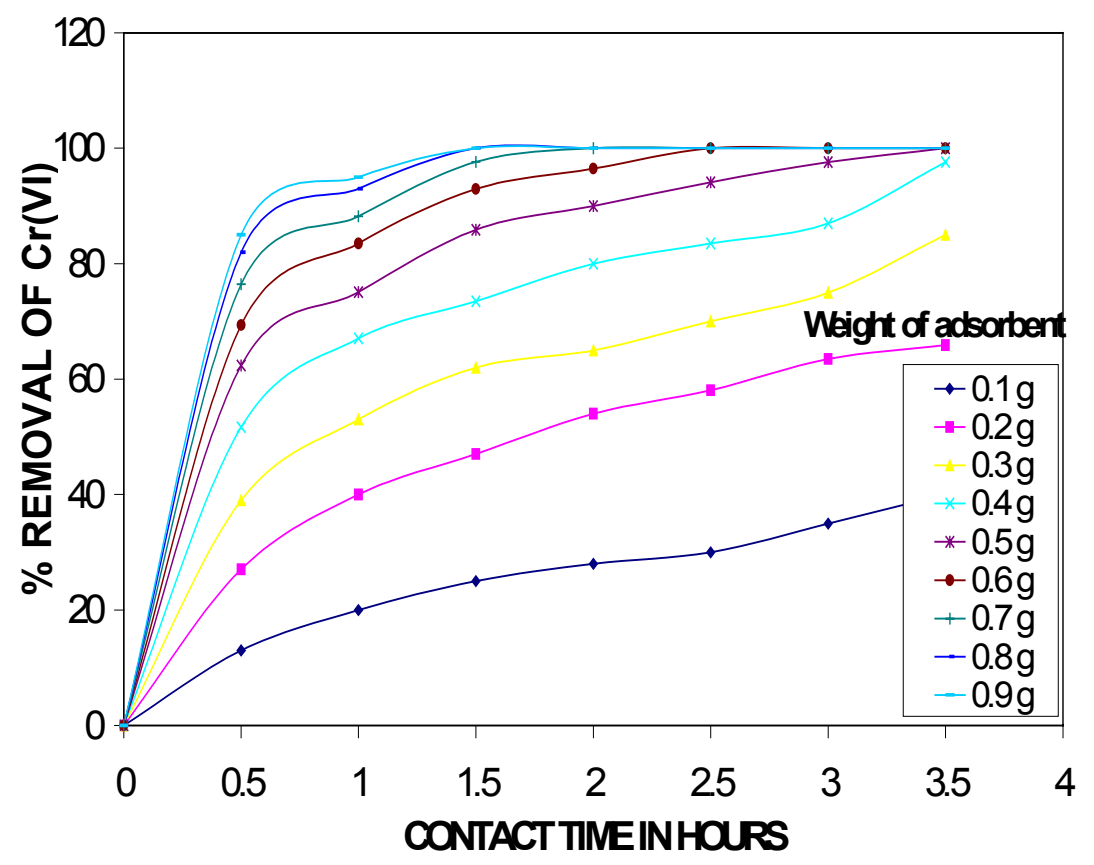

Figure 1. Effects of contact time at different adsorbent (bagasse) doses on Cr (VI) removal. 
time. The removal efficiency is further increased as the dose of bagasse increases from 0.1 to $0.9 \mathrm{~g}$ and the contact time varies from 0.5 to $3.5 \mathrm{hr}$. It is also observed that at $0.5 \mathrm{hr}$ the removal efficiency increased from $27-80 \%$ as the adsorbent dose increased from 0.2 to $0.8 \mathrm{~g}$. If the contact time is raised to $1.0 \mathrm{hr}$, the removal efficiency varies from 38 to $93 \%$ for the same variation of dose (0.2 to $0.8 \mathrm{~g})$.

A removal efficiency of $94 \%$ of $\mathrm{Cr}$ (VI) is observed at a contact time of $1.5 \mathrm{hr}$ with a dose of 0.70 $\mathrm{g} / 50 \mathrm{ml}$. Chand et al. (Shrichand, 1994) observed 30\% removal efficiency of Cr (VI) having initial $\mathrm{Cr}$ (VI) concentration of $10 \mathrm{mg} / 1$, at $\mathrm{pH} 4.38$, the contact time was $1.5 \mathrm{hr}$ and dose of adsorbent was $1.2 \mathrm{~g} / 100 \mathrm{ml}$.

\section{Effects of Adsorbent Dose at Different Contact Time on Chromium Cr (VI) removal}

The effect of various bagasse dose on the removal of $\mathrm{Cr}$ (VI) from the wastewater are shown in Figure 2 .The results indicate an increase in the removal efficiency of Cr (VI) with increase in the dose of raw bagasse up to a certain level, beyond which the removal efficiency remains constant. It is evident that a dose of $0.8 \mathrm{~g} / 50 \mathrm{ml}$ is sufficient to remove $75-100 \% \mathrm{Cr}$ (VI) in $0.5-3.5$ $\mathrm{hr}$. The increase in the removal efficiency with a simultaneous increase in adsorbent dose is due to the increase in surface area and hence more active sites are available for the adsorption of $\mathrm{Cr}(\mathrm{VI})$.

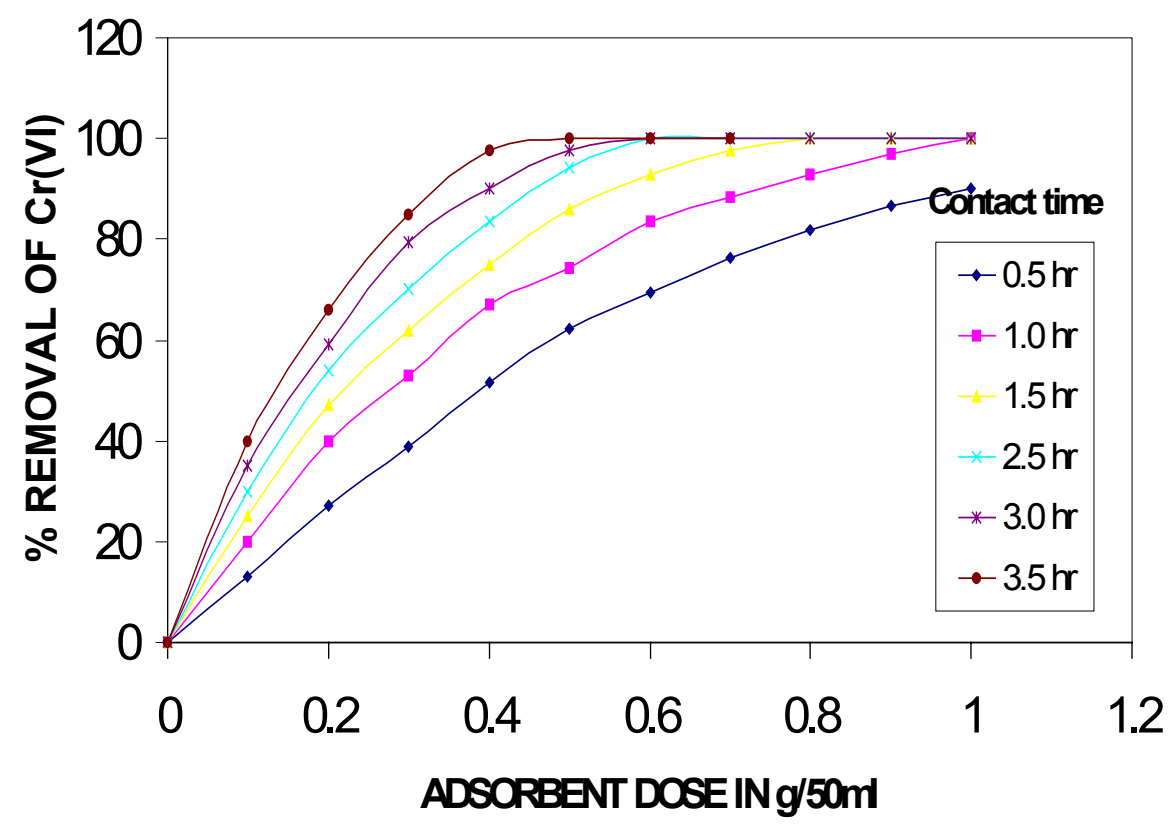

Figure 2. Effects of adsorbent dose at different contact time on $\mathrm{Cr}$ (VI) removal.

\section{Effect of pH on Chromium (VI) Removal}

Effect of $\mathrm{pH}$ on $\mathrm{Cr}$ (VI) removal shows that at lower $\mathrm{pH}$, the $\mathrm{Cr}$ (VI) removal efficiency is higher and at higher $\mathrm{pH}$ the removal efficiency is reduced considerably (Figure 3). At $\mathrm{pH} 1.0$ the removal efficiency is $100 \%$, whereas on increasing the $\mathrm{pH}$ to 3.0 the removal efficiency is reduced to $15 \%$. One of the reasons for the better adsorption capacity observed at low $\mathrm{pH}$ values may be attributed to the large number of $\mathrm{H}^{+}$ions present at these $\mathrm{pH}$ values, which in turn neutralizes the negatively charged hydroxyl groups $(-\mathrm{OH})$ on the adsorbed surface thereby reducing hindrance to the diffusion of dichromate ions. At higher $\mathrm{pH}$, the reduction in adsorption may be due to an 
abundance of $\mathrm{OH}^{-}$ions causing increased hindrance to diffusion of positively charged dichromate ions.

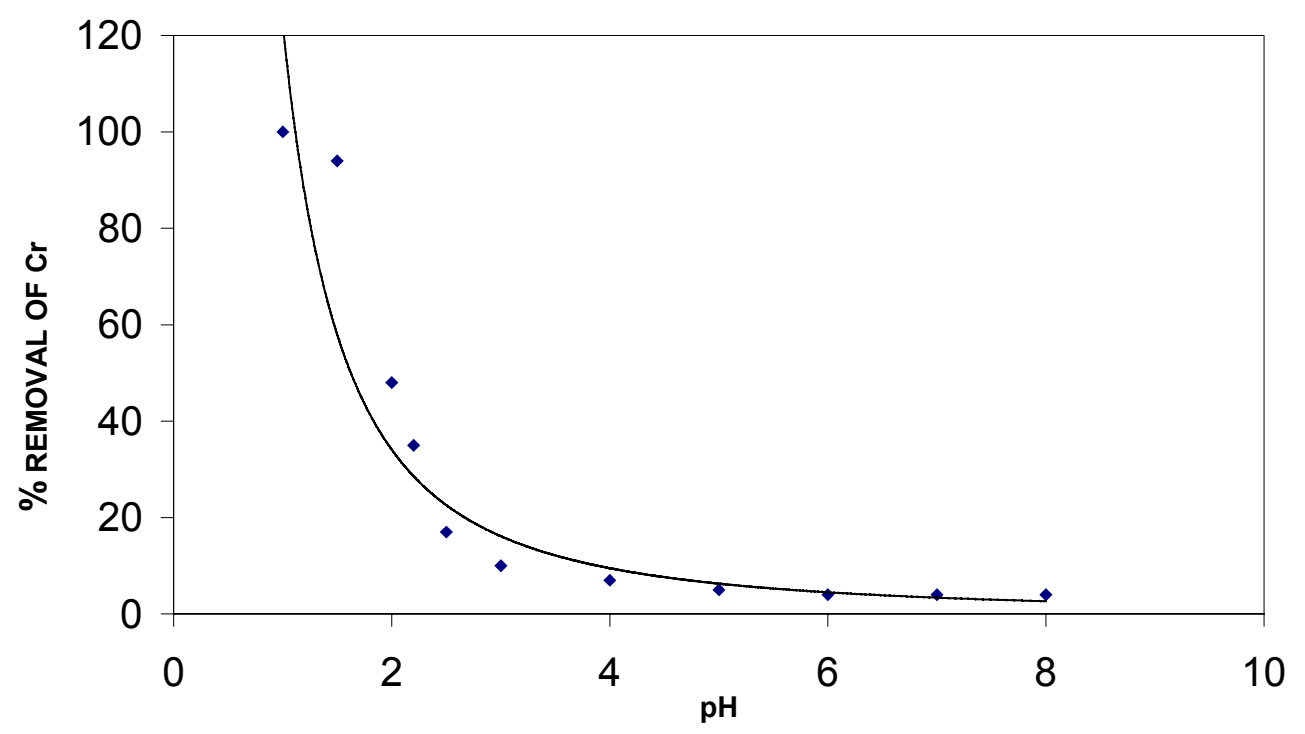

Figure 3. Effects of $\mathrm{pH}$ on $\mathrm{Cr}(\mathrm{VI})$ removal.

\section{Effects of Various Initial Cr (VI) Concentrations on Cr (VI) Removal}

The results of Figure 4 show that at low initial concentrations of chromium (VI) ( 5 to 10 $\mathrm{mg} / \mathrm{l})$ the removal efficiency is higher (70-100\%). The removal efficiency of chromium decreases when chromium concentration is increased beyond $10 \mathrm{mg} / \mathrm{l}$. The removal efficiency is $60 \%$ at a concentration of $20 \mathrm{mg} / \mathrm{l}$ and it decreases to $47 \%$ when chromium concentration was increased to $50 \mathrm{mg} / \mathrm{l}$. In a similar study Chand et al. (Shrichand, 1994) obtained 90\% removal efficiency at a $\mathrm{Cr}$ (VI) concentration of $10 \mathrm{mg} / 1$ in a dose of $1.0 \mathrm{~g} / 100 \mathrm{ml}$ at a contact time of $1.5 \mathrm{hr}$ when the $\mathrm{pH}$ of the solution was 2.0 .

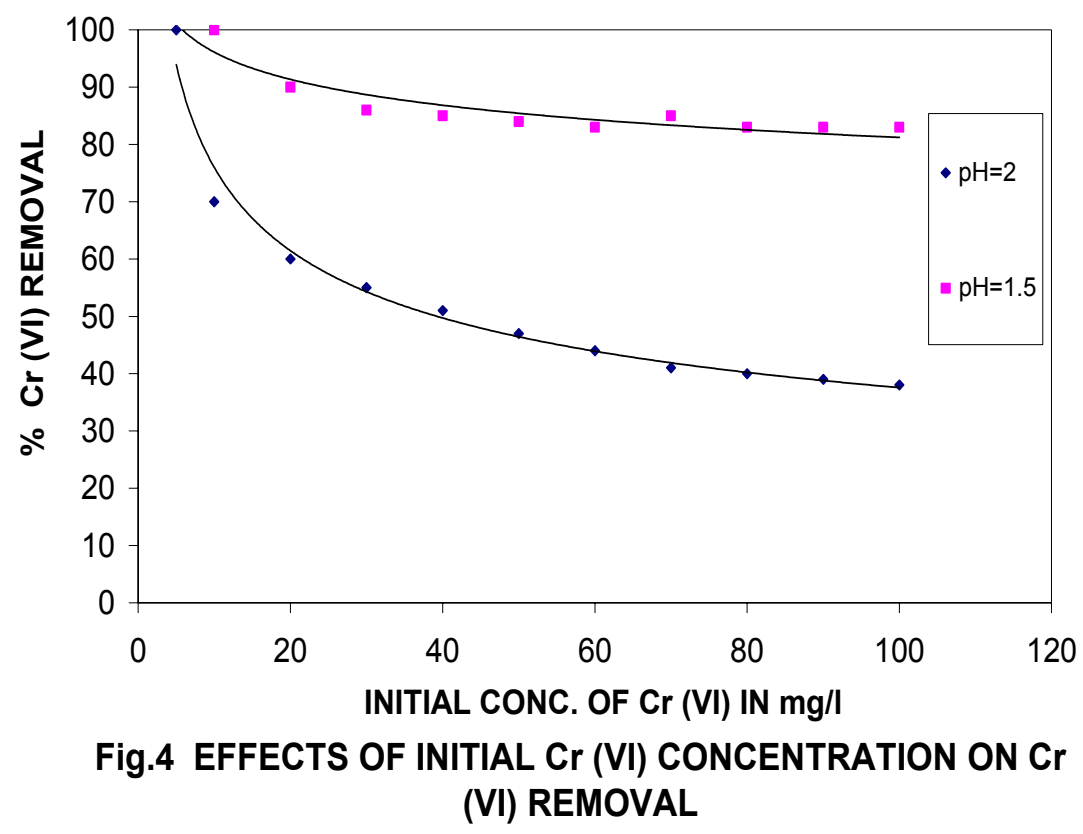




\section{Rate Kinetics}

The adsorption studies (Figure 5) conducted at a fixed initial concentration and varying adsorbent doses were fitted to the linearized Freundlich adsorption isotherm given below,

$$
\log (\mathrm{x} / \mathrm{m}) \quad=\log \mathrm{K}+1 / \mathrm{n} \log \mathrm{Ce}
$$

where, $\mathrm{x} / \mathrm{m}$ is the amount of $\mathrm{Cr}$ (VI) adsorbed per unit mass of adsorbent $(\mathrm{mg} / \mathrm{mg}$ ) and $\mathrm{Ce}$ is the equilibrium concentration of aqueous solution. $\mathrm{K}$ is a constant, which is a measure of adsorption capacity, and $1 / \mathrm{n}$ is a measure of adsorption intensity. The values of the constant $\mathrm{K}$ and $1 / \mathrm{n}$ are 0.0032 and 0.235 respectively.Since the values are less than 1 , it indicates a favorable adsorption (Shrichand, 1994).

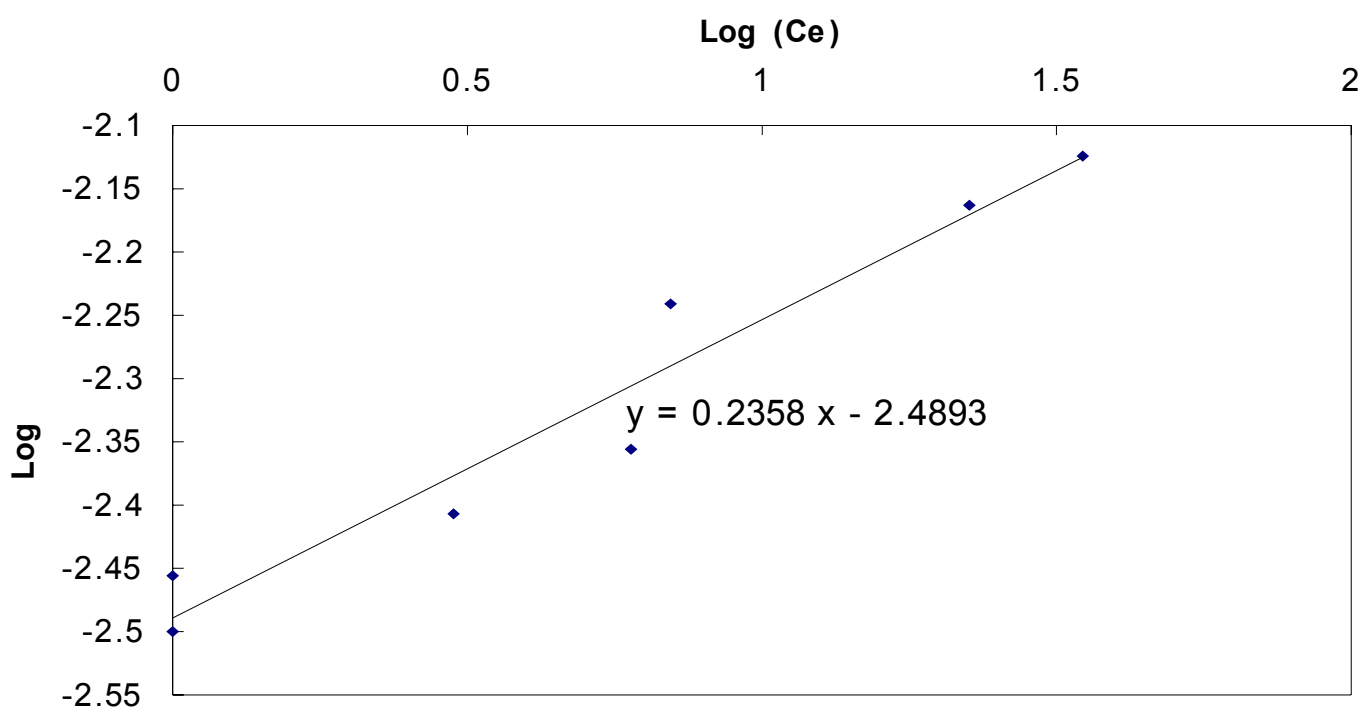

Figure 5. Plot for freundlich isotherm.

\section{Conclusions}

The following conclusions can be drawn from the present study.

- An adsorbent dose of $0.8 \mathrm{~g} / 50 \mathrm{ml}$ is sufficient to remove $80-100 \% \mathrm{Cr}$ (VI) from a solution having an initial concentration of $50 \mathrm{mg} / \mathrm{l}$.

- The data obtained during the present study may be quite helpful in designing a full-scale adsorber for the treatment.

- Before applying raw bagasse for the treatment of wastewater there is a need for further investigations as the acid hydrolysis of cellulose in acidic medium produces alcohol that may increase the expand of the wastewater.

- Raw bagasse exhibits a high degree of $\mathrm{Cr}(\mathrm{VI})$ removal and it can be utilized for the treatment of industrial wastes containing chromium (VI) concentrations between 10-100 mg/l.

- The raw bagasse after adsorption can be burnt for heat recovery and the bagasse ash containing small quantities of $\mathrm{Cr}$ (VI) can be disposed off on low-lying areas.

\section{References}

AYUB, S; ALI, S.I; KHAN, N.A; RAO, R.A.K. 1999. Extraction of Chromium from the wastewater by Adsorption, Environmental Pollution Cont. Journal, 2(5): 27-31. 
AYUB, S; ALI, S.I.; KHAN, N.A; HASAN, S.D. Dec1998. Treatment of Wastewater by Agricultural Wastes, Environmental Pollution Cont.Journal.1(2): Standard Methods for the Analysis Water and Wastewater. $17^{\text {th }}$ ed. APH, AWWA, WPCF, Washington D.C, 1989, 5-8.

BENEFIELD, L.D; JADLEINS, J.F; WEAND, B.L. 1982. Process Chemistry for Water and Wastewater Treatment, Prentice-Hall, Inc; Engle wood Cliffs, New Jersey.

CHAND, S.A; AGGARWAL, V.K; KUMAR, P, 1994. Removal of Hexavelent Chromium from the Wastewater by Adsorption, Indian J. Environ.Hlth 36(3): 151-158.

DEO, N. ALI, M. 1992. Use of a low cost material as an adsorbent in the removal of Cr(VI) from the dilute aqueous solution, IJEP. 12(6): 439-411.

HUANG, C.P.WU. M.H. 1975. Chromium removal by carbon adsorption. J.Water pollut.Cont.Fed.47: 243-46.

LAL, J; SINGH, D.K., 1992. Removal of chromium (VI) from the Aqueous Solution using Waste Tealleaves Carbon. Indian J. Environ.Hlth 34: 108-113.

METACALF, L; EDDY, H.P.1994.Wastewater Engineering Reuse and Disposal, Tata McGrow Hill Pub.Co; New Delhi,

PERIASAMY, K; SRINIVASAN, K; MURUGAN P.K., 1991. Studies on chromium (VI) removal by Activated Groundnut Husk Carbon, Indian J. Environ.Hlth, 31(4): 433-439.

SATYANARAYAN, S., 1995. Sorption of Cr (VI) and Cr (III) from Water by Bitruninous Coal, M.Tech. Thesis, IIT Kanpur.

SHARMA, D.C; FORSTER, C.F, 1993.Removal of Hexvalent Chromium using Sphagnum Mors Peet, Wat.Res, 27(7): 1201-08.

SIDDIQUI, Z.M; PAROOR, S, 1994. Removal of chromium (VI) by different Adsorbents-A comparative Study.IJEP, 14(4): 273-278.

Received 4 March 2000

Accepted 1 June 2000 